\title{
Evaluation the Efficacy of Fungicides and Bio-agents against Fusarium oxysporum under in vitro and in vivo Conditions
}

\author{
Sita Ram Bana, Manoj Kumar Meena, Neeraj Kumar Meena and Nithin B. Patil*
}

Department of Plant Pathology, Sam Higgin bottom Institute of Agriculture, Technology and

Sciences Deemed-to-be University Allahabad, Uttar Pradesh, India

*Corresponding author:

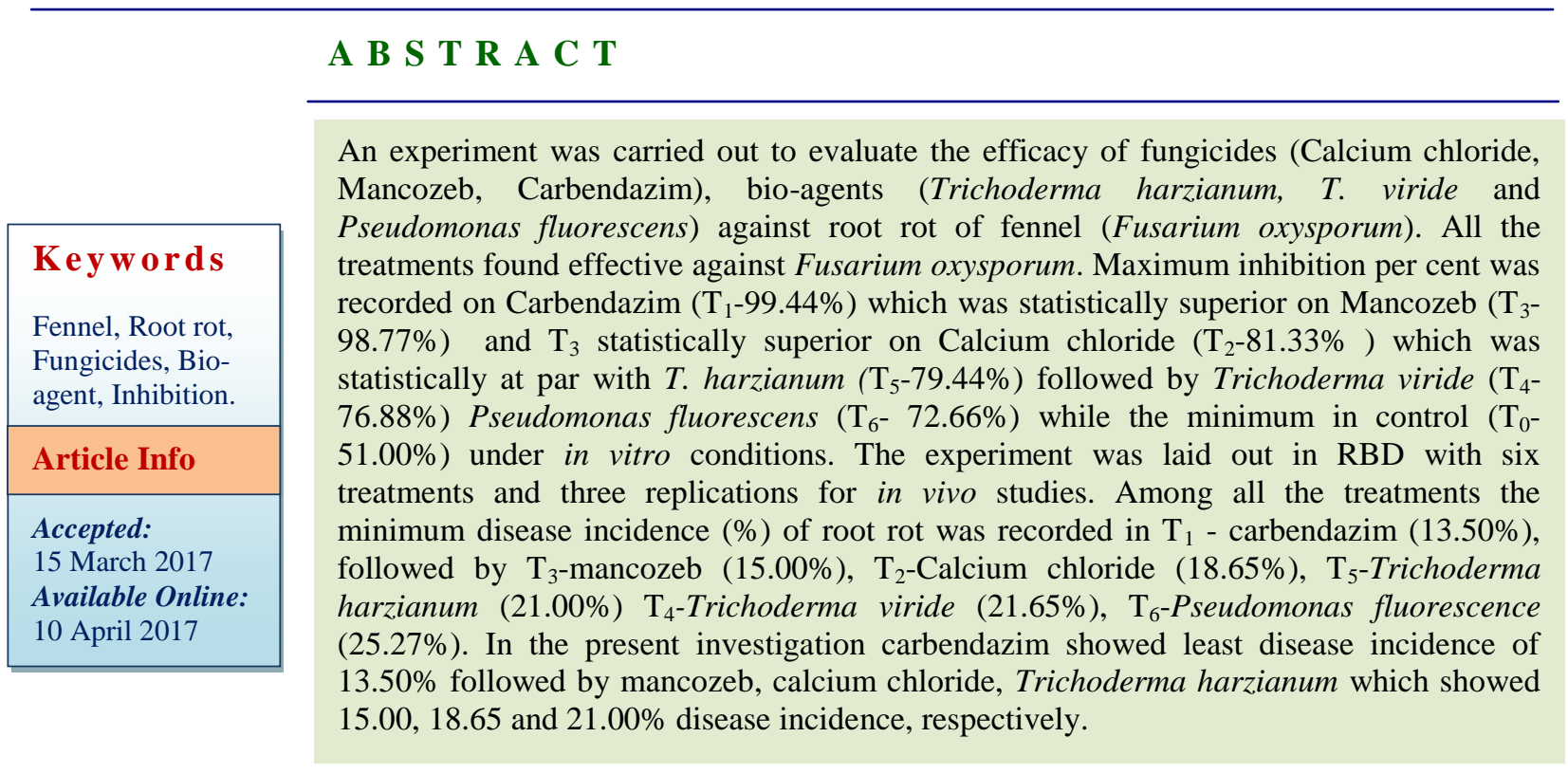

\section{Introduction}

Fennel (Foeniculum vulgare Mill.) is one of the most important seed spices belong to family Apiaceae. All parts of fennel plant viz., roots, leaves and volatile oil present in the seeds have medicinal values. Leaves are diuretic and roots are purgative. Seeds are aromatic, stimulant carminative and useful in diseases of chest, lungs, spleen, and kidney. It is also used to cure the diseases like cholera, bite, disorders of nervous system, cough and cold, constipation, dysentery and diarrhea. It is considered a good vermicide against hook worm. Hot infusion of fruits is used in indigenous medicine to increase lacteral secretion and to stimulate sweating. The consumption of fennel seeds also aid weight loss and longevity. Fennel oil is used in preparation of medicines for treatment of post menopausal syndrome and regulate menstrual period (Agarwal et al., 2001). India is the largest producer, consumer and exporter of seed spices in the world. The major growing belt spreads from arid to semi-arid regions covering large area in Gujarat, Rajasthan and Uttar Pradesh. In the Uttar Pradesh area under fennel is 842 ha with production of 740 tones 
and the productivity $380 \mathrm{~kg} / \mathrm{ha}$ (Anonymous, 2011).

Fennel is attacked by a number of diseases viz. root rot (Fusarium oxysporum), damping off of seedling (Phytophthora syringae), powdery mildew (Erysiphepolygoni D.C. and Leveillula taurica (Lev.) Arnaud), leaf spot (Cercospora traversiana Sacc.) and collar rot (Rhizoctoniasolani Kuhn). In India, the disease has been prevalent in all the fennel growing states. It cause on an average 10 to $25 \%$ loss in yield and the damage has been observed to extend up to $60 \%$ and $43 \%$ at seedling and adult stages. Root rot in fennel can be observed 30-35 days after sowing. The disease appears at seedling (SeptemberOctober) and reproductive stages (FebruaryMarch) of the crop under field conditions. The infected plants show yellowing and withering of upright foliage. The infection extends up to lower portion of the stem at ground level and a dark brown discolouration of the affected portion of the stem is observed with whitish fungus growth on the affected portion of the stem at ground level (Gupta and Srivastava, 1976). A major limiting factors in profitable cultivation of this crop in Uttar Pradesh is attack of several diseases mainly caused by fungi and amongst them root rot caused by Fusarium oxysporum causes considerable damage in semi-arid areas where soil are sandy loam.

\section{Materials and Methods}

\section{In vitro efficacy of fungicides}

Efficacy of two systemic fungicides against mycelial growth of $F$. oxysporium was tested by poisoned food technique (Nene and Thapliyal, 1979). Four different concentrations viz., 50, 100, 200 and 300 ppm of each fungicide was tested. Required quantity of each fungicide was added separately to sterilized medium, mixed thoroughly and poured in sterilized $9 \mathrm{~cm}$ diameter glass petri plates and allowed to solidify. Five replications were maintained for each treatment. A control was also maintained where medium was not supplemented with any fungicides. Each plate was inoculated with $5 \mathrm{~mm}$ disc with the help of sterilized cork borer from the edge of the fungal culture and incubated at $25 \pm 2{ }^{\circ} \mathrm{C}$ for 7 days. The colony diameter (two diagonals) of the test fungus was recorded and per cent growth inhibition was calculated by following formula (Vincent's, 1947):

Per cent growth inhibition $=\frac{\text { C - T }}{\text { C }}$ where,

$\mathrm{C}=$ diameter of the colony in check (average of both diagonals)

$\mathrm{T}=$ diameter of colony in treatment (average of both diagonals)

\section{In vitro efficacy of bioagent}

In vitro efficacy of three bio-control agents i.e. Trichoderma harzianum, T. viride and Pseudomonas fluorescens were tested by using dual culture plate method on PDA medium (Singh et al., 2005). PDA was used as the basal medium. $20 \mathrm{ml}$ of sterilized melted PDA was poured in each $9 \mathrm{~cm}$ diameter glass Petri plates and allowed to solidify. After 12 hours of pouring, these Petri plates were inoculated with $5 \mathrm{~mm}$ discs with the help of sterilized cork borer from the edge taken from 7 days old culture of $F$. oxysporum and antagonistic agents. Both were placed separately at equal distance on the periphery of the Petri plates. Inoculated Petri plates were incubated at $25 \pm 2^{\circ} \mathrm{C}$ in BOD incubator for 7 days. After the incubation area of inhibition zone was measured $(\mathrm{cm})$ from the difference between mycelial growth of the pathogen and antagonists. Inhibition zone was measured $(\mathrm{cm})$ in comparison with the control 
(Yadav and Majumdar, 2004). Five replications were maintained for each treatment. A field trial was conducted during Rabi season 2013-14 at Department of Plant Pathology, Sam Higgin bottom Institutes of Agriculture, Technology and Sciences, Allahabad (Deemed to be University) UP, India to test the efficacy of six different fungicides; bio-agents against fennel root rot disease. Fennel crop variety $\mathrm{Co}-1$ was raised during Rabi season in a randomized block design with three replications. A spacing of $50 \times 30 \mathrm{~cm}$ was adopted in plots of $2 \times 1 \mathrm{~m}$ and six treatments were imposed viz., Calcium chloride (2\%), Carbendazim @ (50\% WP), Mancozeb @ (75\% WP), Trichoderma harzianum $(10 \mathrm{~g} / \mathrm{l})$, Trichodermaviride $(10 \mathrm{~g} / \mathrm{l})$ and Pseudomonas fluorescens (10g/l) upon untreated control. The fungicides were sprayed soon after the first appearance of the disease. The treatments were repeated three times at 15 days interval and a total of three sprayings were taken up for each fungicides, bio-agents and neem leaf extract. Observations on the disease intensity were recorded 10 days after the last spray using the scale of 0-9 (Mayee and Datar, 1986) on randomly selected 5 plants of upper, middle and lower leaves. From total grades of 25 leaves, the percent disease index (PDI) was calculated.

Disease intensity $(\%)=$

Sum of all disease rating

Total number of leaves $\times$ maximum grade $\mathrm{x} 100$

\section{Results and Discussion}

Radial growth and per cent inhibition of oxysporum

The results (Tables 1 and 2 and Fig. 1) revealed that average mycelial growth was recorded in test treatments from 0.05 to 4.41 $\mathrm{cm}$. However, significantly minimum average mycelia growth was recorded in Carbendazim $\left(\mathrm{T}_{1}, .05 \mathrm{~cm}\right)$. This was statistically superior on Mancozeb $\left(\mathrm{T}_{3}, 11 \mathrm{~cm}\right)$ statistically superior also on Calcium chloride $\left(\mathrm{T}_{2^{-}} 1.68 \mathrm{~cm}\right)$ followed by Trichoderma harzianum $\left(\mathrm{T}_{5}, 1.85\right.$ $\mathrm{cm}), T$. viride $\left(\mathrm{T}_{4} .2 .08 \mathrm{~cm}\right), P$. fluorescens $\left(\mathrm{T}_{6}, 2.46 \mathrm{~cm}\right)$ as compared to control $\left(\mathrm{T}_{0}\right.$, $4.41 \mathrm{~cm})$.

The data presented on inhibition $\%$ of mycelial growth as influenced by fungicides and bio-control agents are given (Table 2). A significant difference the inhibition $\%$ of mycelia growth was observed among the treatment. Maximum inhibition per cent was recorded on Carbendazim ( $\left.\mathrm{T}_{1}, 99.44 \%\right)$ which was statistically superior on Mancozeb $\left(\mathrm{T}_{3}\right.$, $98.77 \%$ ) and $\mathrm{T}_{3}$ statistically superior on Calcium chloride $\left(\mathrm{T}_{2} .81 .33 \%\right)$ which was statistically at par with $T$. harzianum $\left(\mathrm{T}_{5}\right.$, $79.44 \%)$ followed by $T$. viride $\left(\mathrm{T}_{4}, 76.88 \%\right)$ P. fluorescens $\left(\mathrm{T}_{6}, 72.66 \%\right)$ while the minimum in control $\left(\mathrm{T}_{0}, 51.00 \%\right)$. In in vitro evaluation of fungicides is a handy tool to test large number of fungicides in the present study, the Carbendazim among fungicide were found to be highly effective inhibiting.

The results of the present experiment evaluated that fungicides tested in this study exhibited antagonistic activity against $F$. oxysporum. The test antagonist $T$. harzianum (79.44\%) was most effective antagonist and inhibited the radial growth of pathogen which was statistically at par with $T$. viride $(76.88 \%)$ the probable reason for such finding may be the more than on mechanism like antibiosis, lysis and competition ware exhibited by Trichoderma spp., might have developed on Fthe hyphae of other fungi. T. harzianum and T. viride an effective biological control agent against Fusarium spp (Sivan and Chet, 1986; Loban, 1990; Deshmukh and Raut, 1992; Verma and Dohroo, 2005). 
Table.1 Inhibitory effect on radial growth of Fusarium oxysporum

\begin{tabular}{|l|c|c|c|c|c|c|c|}
\hline \multirow{2}{*}{ Treatments } & \multicolumn{6}{|c|}{ Radial growth of Fusarium oxysporum (cm) } \\
\cline { 2 - 8 } & $24 \mathrm{hrs}$ & $48 \mathrm{hrs}$ & $72 \mathrm{hrs}$ & $96 \mathrm{hrs}$ & $120 \mathrm{hrs}$ & $144 \mathrm{hrs}$ & $168 \mathrm{hrs}$ \\
\hline $\mathrm{T}_{1}$-Carbendazim & 00 & 00 & 00 & 00 & 00 & .10 & .25 \\
\hline $\begin{array}{l}\mathrm{T}_{2} \text {-Calcium } \\
\text { chloride }\end{array}$ & .62 & 1.26 & 1.70 & 1.75 & 1.90 & 2.07 & 2.50 \\
\hline $\mathrm{T}_{3-\text { Mancozeb }}$ & 00 & 00 & 00 & 00 & 00 & .25 & .55 \\
\hline $\begin{array}{l}\mathrm{T}_{4-} \text { Tricoderma } \\
\text { viride }\end{array}$ & .20 & 1.20 & 1.60 & 2.25 & 2.90 & 3.10 & 3.31 \\
\hline $\mathrm{T}_{5}$ T. harzianum & .60 & 1.55 & 1.75 & 2.08 & 2.12 & 2.30 & 2.55 \\
\hline $\begin{array}{l}\mathrm{T}_{6-} \\
\text { Pseudomonas } \\
\text { fluorecens }\end{array}$ & .65 & 2.00 & 2.20 & 2.85 & 3.02 & 3.50 & 4.05 \\
\hline \begin{tabular}{l}
$\mathrm{T}_{0-}$ Control \\
\hline F-Test
\end{tabular} & .74 & 2.95 & 3.69 & 4.53 & 5.60 & 6.55 & 7.85 \\
\hline SEm+. & 8.41 & 3.72 & 3.05 & 2.082 & 1.345 & 1.72 & 1.529 \\
\hline CD at 5\% & 0.047 & 0.569 & 0.068 & 0.058 & 0.047 & 0.058 & 0.066 \\
\hline
\end{tabular}

Table.2 Radial growth and per cent inhibition of Fusarium oxysporum as affected by different treatments

\begin{tabular}{|l|c|c|}
\hline \multicolumn{1}{|c|}{ Treatments } & $\begin{array}{c}\text { Radial growth of pathogen } \\
(\mathbf{c m})\end{array}$ & Per cent inhibition \\
\hline $\mathrm{T}_{1}$-Carbendazim & .05 & 99.44 \\
\hline $\mathrm{T}_{2-}$ Calcium chloride & 1.68 & 81.33 \\
\hline $\mathrm{T}_{3-}$ Mancozeb & .11 & 98.77 \\
\hline $\mathrm{T}_{4}$ - Trichoderma viride & 2.08 & 76.88 \\
\hline $\mathrm{T}_{5-\text { T. } \text { harzianum }}$ & 1.85 & 79.44 \\
\hline $\mathrm{T}_{6-\text { Pseudomonas fluorescens }}$ & 2.46 & 72.66 \\
\hline $\mathrm{T}_{0-}$ Control & 4.41 & 51.00 \\
\hline
\end{tabular}


Table.3 Per cent disease incidence of root rot on fennel as affected by different treatments (in Field and pot condition)

\begin{tabular}{|c|c|c|c|c|}
\hline $\begin{array}{l}S . \\
\text { No.1 }\end{array}$ & Treatments & $\begin{array}{l}\text { Dose } \\
\text { (g/kg) }\end{array}$ & $\begin{array}{l}\text { Per cent } \\
\text { disease } \\
\text { incidence }\end{array}$ & $\begin{array}{l}\text { Per cent } \\
\text { disease } \\
\text { control }\end{array}$ \\
\hline 1. & Carbendazim & $2 g$ & 13.50 & 74.36 \\
\hline 2. & Calcium chloride & $3 g$ & 18.65 & 64.58 \\
\hline 3. & Mancozeb & $3 g$ & 15.00 & 71.51 \\
\hline 4. & Trichoderma viride & $4 \mathrm{~g}$ & 21.65 & 58.88 \\
\hline 5. & Trichoderma harzianum & $4 \mathrm{~g}$ & 21.00 & 60.11 \\
\hline 6. & Pseudomonas fluorescens & $10 \mathrm{~g}$ & 25.27 & 52.03 \\
\hline \multirow[t]{5}{*}{7.} & Check (inoculated) & & 52.65 & - \\
\hline & overall mean & & 23.96 & \\
\hline & F-test & & $\mathrm{S}$ & \\
\hline & $\mathrm{SEm}+$ & & 1.02 & \\
\hline & $\mathrm{CD}$ at $5 \%$ & & 1.23 & \\
\hline
\end{tabular}

Fig.1 Inhibitory effect on radial growth of Fusarium oxysporum

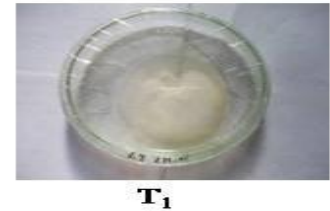

$\mathbf{T}_{1}$

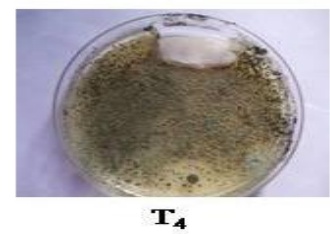

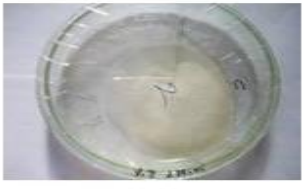

$\mathbf{T}_{\mathbf{2}}$

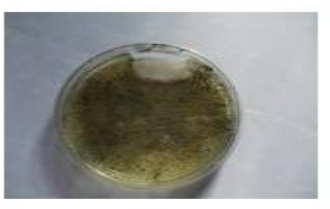

$\mathbf{T}_{\mathbf{S}}$

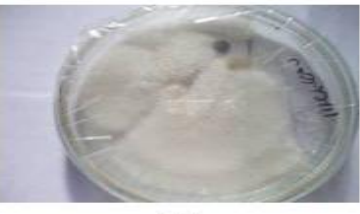

$\mathbf{T}_{\mathbf{0}}$

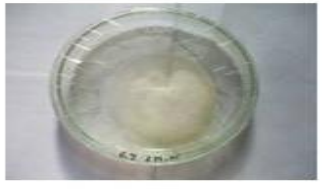

$\mathbf{T}_{3}$

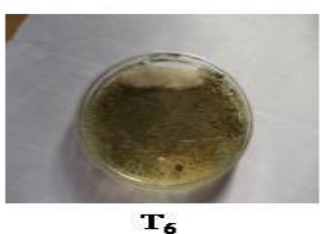

Per cent disease incidences of root rot on fennel as affected by different treatments (in field and pot condition)

Efficacy of bio- agents, calcium chloride and fungicides at their respective does were further tested in vivo condition against $F$. oxysporum, root rot causing pathogen, with respect of per cent disease incidence of fennel.
The data presented in table 3 showed that all the treatments are significantly effective over control. Among all the treatments the minimum disease incidence $(\%)$ of root rot was recorded in $\mathrm{T}_{1}$ - carbendazim (13.50\%), followed by $\mathrm{T}_{3^{-}}$mancozeb $(15.00 \%), \mathrm{T}_{2}-$ calcium chloride $(18.65 \%), \mathrm{T}_{5}-T$. harzianum $(21.00 \%) \mathrm{T}_{4}-T$. viride $(21.65 \%), \mathrm{T}_{6}-P$. fluorescence $(25.27 \%)$. In the present investigation carbandazim showed least 
disease incidence of $13.50 \%$ followed by mancozeb, calcium chloride, Trichoderma harzianum which showed 15.00,18.65 and $21.00 \%$ disease incidence, respectively. Jahagirdar et al., (2002) reported that seed treatment with biocontrol agent, Trichoderma viride $(4 \mathrm{~g} / \mathrm{kg})$ of seed is recommended as ecofriendly, approach for the management of chickpea wilt. Ghasolia and Jain (2003) reported that the efficacy of the carbendazim, thiram, captan, tebuconazole against Fusarium wilt in cumin and they found that carbendazim treated seed showed highest value for seed germination, root and shoot length and vigour index and lower pre- and post emergence mortality and also number of seedlings showing wilt symptoms.

\section{References}

Agarwal, S., Sastri, E.V.D. and Sharma, R.K., 2001. Seed Spices, Production Quality, Export, 1, 109-114.

Anonymous, 2011. Second annual Report of All India Co-ordinated Spices Improvement Project Sukhadia University, Jobner (Rajasthan), pp. 39.

Deshmukh, P.P. and Raut, J.G., 1992. Antagonism by Trichoderma spp. On five plant pathogenic fungi. New Agriclturist, 3(2), 127-130.

Ghasolia and Jain, R.K., 2003. Seed treatment for the control of Fusarium wilt in cumin. Journal of Phytopathological Research. 16 (1), 67-72.

Gupta, J.H. and Srivastava, U.P., 1976. A new root rot of fennel caused by Fusarium solani. Journal of Mycology and Plant Pathology, 8, 206.

Jahagirdar S., Yenjerappa, S.T., Ravi, M.R. and
Jamadar, M.M., 2002. Field evaluation of biocontrol agent chick pea wilt. Legum Res., 25(40), 299-300.

Loban, V.L., 1990. Distribution and species composition of wheat root rot pathogens in Ethiopia. Mikologiya fitopathologiya, 24, 74-76.

Mayee and Datar,1986. Phytopathology. Technical bulletin-1, MAU, Parbhani pp 80-81.

Nene, Y.L. and Thapliyal, P.N., 1979. Fungicides in Plant Disease Control. Oxford \& IBH Pub. Co., New Delhi, pp. 507.

Singh, D., Chhonkari, P.K. and Dwivedi, B.S., 2005. Manual on soil, plant and water analysis. Westville Publishing house, New Delhi, pp. 23-25.

Sivan, A. and Chet, I., 1986. Possible mechanism for control of Fusarium spp. by Trichoderma harzianum. In 1986 British Crop protection conference, pests and disease vol. 2 Thornton Health, U.K.; Bristish Crop Protection Council, pp. 865-872.

Verma, S. and Dohoo, N.P., 2005. Evaluation of fungicides against Fusarium oxysporum $\mathrm{f}$. fsp. Pisi causing wilt of autumn pea in Himachal Pradesh, Pl. Dis. Res.17 (2), 261-268.

Vincent, J.M., 1927. Distortion of fungal hyphae in presence of certain inhibitors. Nature.159, 850.

Yadav, R.K. and Majumdar, V.L., 2004. Efficacy of plant extracts, biological agents and fungicides against Lasiodiplodia theobroma incited die back of guava (Psidium guajva). Journal of Mycology and Plant Pathology, 34, 415417.

\section{How to cite this article:}

Sita Ram Bana, Manoj Kumar Meena, Neeraj Kumar Meena and Nithin B. Patil. 2017. Evaluation the Efficacy of Fungicides and Bio-agents against Fusarium oxysporum under In Vitro and in vivo Conditions. Int.J.Curr.Microbiol.App.Sci. 6(4): 1588-1593.

doi: https://doi.org/10.20546/ijcmas.2017.604.195 